\title{
Viscum pleurodesis is as effective as talc pleurodesis and tends to have less adverse effect
}

\author{
YongJin Chang ${ }^{1}$ (D) $\cdot$ DeogGon Cho $^{1} \cdot \mathrm{KyuDo}^{\mathrm{Cho}}{ }^{1} \cdot \mathrm{MinSeop} \mathrm{Cho}^{1}$
}

Received: 18 July 2019 / Accepted: 6 March 2020 / Published online: 12 March 2020

(C) The Author(s) 2020

\begin{abstract}
Purpose Many patients diagnosed with advanced cancer have malignant pleural effusion that does not respond to chemotherapy or radiation therapy. These patients often have respiratory symptoms, especially dyspnea. In order to relieve these symptoms, various procedures including chemical pleurodesis have been performed. Although talc is the most widely used and effective sclerosing agent, there it has various adverse effects. The objective of this study was to determine whether Viscum (ABNOVA Viscum ${ }^{\circledR}$ Fraxini Injection, manufactured by ABNOVA GmbH, Germany) could be used as an agent to replace talc in clinical practice.

Methods Data of 56 patients with malignant pleural effusion who received chemical pleurodesis after tube thoracostomy from January 2003 to December 2017 were retrospectively reviewed to analyze clinical course and response after pleurodesis with each agent.

Results After pleurodesis, changes in numeric rating scale (NRS) was $1.4 \pm 1.6$ in the talc group and $0.5 \pm 1.5$ in the Viscum group $(p=0.108)$. Changes in white blood cell counts after pleurodesis were $4154.8 \pm 6710.7$ in the talc group and $3487.3 \pm$ 6067.7 in the Viscum group $(p=0.702)$. Changes in C-reactive protein (CRP) were $9.03 \pm 6.86$ in the talc group and $6.3 \pm 7.5$ in the Viscum group $(p=0.366)$. The success rate of pleurodesis was $93.3 \%$ in the talc group and $96 \%$ in the Viscum group $(p=$ 0.225).

Conclusion Viscum pleurodesis showed comparable treatment results with talc pleurodesis while its adverse effects such as chest pain and fever tended to be relatively weak.
\end{abstract}

Keywords Malignant pleural effusion $\cdot$ Chemical pleurodesis $\cdot$ Talc $\cdot$ Viscum

\section{Introduction}

The ultimate goal of treatment for patients with malignant pleural effusion (MPE) is to increase quality of life during life

YongJin Chang

tsmate@hanmail.net

DeogGon Cho

ebstein8@daum.net

KyuDo Cho

kyudias@ catholic.ac.kr

MinSeop Cho

minseop@catholic.ac.kr

1 Department of Thoracic and Cardiovascular Surgery, St. Vincent's Hospital, College of Medicine, The Catholic University of Korea, Seoul, Republic of Korea expectancy. These patients often have respiratory symptoms. Repeat thoracentesis, pig tailed catheter drainage, or tube thoracostomy is often used to relieve patient's symptoms. However, such procedure itself can degrade the quality of life. Therefore, chemical pleurodesis is generally recommended to help patients feel at ease. In the past and now, talc is generally used as a sclerosing agent for chemical pleurodesis $[1,2]$. Many researchers have made efforts to select sclerosing agents that are as effective as talc. Unfortunately, previous studies have focused on the "final therapeutic outcome" of chemical pleurodesis using talc and several sclerosing agents without focusing on "patient's discomfort" during pleurodesis.

The authors introduced Viscum (ABNOVA Viscum ${ }^{\circledR}$ Fraxini Injection, manufactured by ABNOVA GmbH, Germany) as an alternative agent for talc and applied it to patients. The purpose of this study to compare the final therapeutic outcome of chemical pleurodesis using talc and Viscum based on various values related to clinical course. 
The usefulness of Viscum in chemical pleurodesis for patients with MPE was also determined.

\section{Materials and methods}

After obtaining institutional review board approval from the Catholic University of Korea, a retrospective review was conducted of 56 consecutive patients with MPE who received chemical pleurodesis after tube thoracostomy on bedside at St. Vincent's Hospital, South Korea from January 2003 to December 2017. The medical records of each patient were reviewed and patients' characteristics were collected. Before and after the procedure, drainage count, vital sign, lab data, pain score as NRS, and finding of plain chest x-ray and chest CT were investigated to analyze clinical course and response after chemical pleurodesis in each agent. The response rate in pleural effusion was assessed by plain chest $\mathrm{x}$-ray examination within 4 weeks after the last pleurodesis [3].

\section{Talc slurry pleurodesis via chest tube}

We injected $25 \mathrm{mg}$ of pethidine intravenously prior to the procedure to patient for pain control. A dose of $2 \mathrm{~g}$ of sterile, asbestos-free talc (Steritalc $\AA$ F2, manufactured by Novatech, France) mixed with $100 \mathrm{ml}$ of sterile saline, was instilled through the chest tube, which was clamped for $2 \mathrm{~h}$ after the procedure. Patient's position change was carried out for $2 \mathrm{~h}$ every $10 \mathrm{~min}$. Plain chest $\mathrm{x}$-ray was taken $30 \mathrm{~min}$ after the procedure was over. Chest drain was removed when chest radiograph confirmed satisfactory lung expansion and total 24-h drainage was less than $150 \mathrm{ml}$ without air leak. Our policy was to observe at least 1 day after removing the chest tube. If there was no change in chest $\mathrm{x}$-ray, the patient was discharged.

\section{Viscum pleurodesis via chest tube}

A dose of $100 \mathrm{mg}$ of Viscum mixed with $50 \mathrm{ml}$ of sterile saline was instilled through the chest tube, which was clamped for $3 \mathrm{~h}$ after the procedure. The patient's position change was carried out for $3 \mathrm{~h}$ every $10 \mathrm{~min}$. Pain control and postprocedure progression were the same as those for talc slurry pleurodesis described above.

All procedures were performed in the same way. The procedure was performed under local anesthesia using $2 \%$ lidocaine on bedside. The chest tube was inserted with $28 \mathrm{Fr}$ in the case of "total white-out" and 24Fr for others.

\section{Statistical analysis}

All descriptive data were expressed as frequency and mean \pm standard deviation. Frequencies were compared using $\mathrm{x}^{2}$ or
Fisher's exact test for categorical variables and independent two-sample $t$ test for continuous variables. The IBM SPSS software ver. 20.0 (IBM Corp., Armonk, NY, USA) was used for the analysis. Differences between groups were considered to be statistically significant when $p$ value was less than 0.05 .

\section{Results}

\section{Patient characteristics}

Among a total of 56 patients, thirty patients underwent talc pleurodesis and twenty-six patients underwent Viscum pleurodesis. Only those patients whose lung reexpansion was confirmed on chest $\mathrm{x}$-ray after tube thoracostomy were included. Characteristics of each patient group are shown in Table 1. There were no significant differences in patient characteristics between the two groups except for male gender (talc vs. Viscum: 16 vs. $5, p=0.009$ ) and positive cytology $(21.7 \%$ vs. $72.7 \%, p=0.001)$.

\section{Clinical findings after talc pleurodesis}

Body temperature (high fever within 2 days), WBC, and CRP were elevated after talc pleurodesis. Body temperature increased from $36.6 \pm 0.3$ to $37.7 \pm 0.7^{\circ} \mathrm{C}$, WBC increased from $7101.7 \pm 2927.2$ to $12,046 \pm 6208.3 \mathrm{cells} / \mathrm{mm}^{3}$, and CRP increased from $9.62 \pm 8.85$ to $16.09 \pm 9.04 \mathrm{mg} / \mathrm{dL}$. The degree of pain measured by NRS was increased from $1.4 \pm 1.1$ to 2.7 \pm 1.3 . After talc pleurodesis, it took 4.6 days to remove the chest tube. Total drainage amount was $476.0 \pm 601.4 \mathrm{ml}$.

Table 1 Patient characteristics before pleurodesis $(n=57)$

\begin{tabular}{llll}
\hline & Talc $(n=30)$ & Viscum $(n=27)$ & $P$ value \\
\hline Age (year) & $60.2 \pm 17.9$ & $64.9 \pm 14.6$ & 0.328 \\
Gender (M) & $16(53.3 \%)$ & $4(23.5 \%)$ & 0.047 \\
Type of cancer & & & 0.305 \\
Lung cancer & $8(26.7 \%)$ & $7(25.9 \%)$ & \\
Breast cancer & $8(26.7 \%)$ & $9(33.3 \%)$ & \\
Ovarian cancer & $2(6.7 \%)$ & $6(22.2 \%)$ & \\
Others & $12(40 \%)$ & $5(18.5 \%)$ & \\
Total drainage (ml) & $2883 \pm 2104$ & $3298 \pm 1466$ & 0.433 \\
Body temperature $\left({ }^{\circ} \mathrm{C}\right)$ & $36.6 \pm 0.3$ & $36.5 \pm 0.3$ & 0.342 \\
Pain (NRS) & $1.4 \pm 1.1$ & $1.6 \pm 1.0$ & 0.503 \\
WBC (cells/mm $\left.{ }^{3}\right)$ & $7101.7 \pm 2927.2$ & $8482.4 \pm 2978.2$ & 0.134 \\
CRP (mg/dL) & $9.62 \pm 8.85$ & $5.16 \pm 4.67$ & 0.163 \\
White-out on x-ray, $\%$ & $5(16.7 \%)$ & $10(58.8 \%)$ & 0.334 \\
Location of effusion (Rt.) & $19(63.3 \%)$ & $8(47.1 \%)$ & 0.278 \\
Follow up (m) & $5.4 \pm 8.1$ & $2.8 \pm 3.3$ & 0.217 \\
\hline
\end{tabular}

$N R S$ numeric rating scale, $W B C$ white blood cell, $C R P$ C-reactive protein 


\section{Clinical findings after Viscum pleurodesis}

Viscum pleurodesis also showed similar pattern to talc. Body temperature increased from $36.7 \pm 0.4$ to $37.7 \pm$ $0.6{ }^{\circ} \mathrm{C}$, WBC increased from $8450.8 \pm 2679.5$ to $14,109 \pm 5203.3$ cells $/ \mathrm{mm}^{3}$, and CRP also increased from $4.75 \pm 4.35$ to $12.3 \pm 6.6 \mathrm{mg} / \mathrm{dL}$. The NRS rose from $2.0 \pm 1.5$ to $2.5 \pm 1.7$. It took $5.2 \pm 4.2$ days to remove the chest tube. Total drainage amount was 756.0 $\pm 1048.4 \mathrm{ml}$ (Table 2).

\section{Changes of clinical features before and after pleurodesis between the two groups}

Body temperature was increased $1.1 \pm 0.7{ }^{\circ} \mathrm{C}$ in the talc group and $1.0 \pm 0.6{ }^{\circ} \mathrm{C}(p=0.699)$ in the Viscum group. WBC was increased $4154.8 \pm 67,110.7$ cells $/ \mathrm{mm}^{3}$ in the talc group and $3487.3 \pm 6067.7$ cells $/ \mathrm{mm}^{3}(p=0.702)$ in the Viscum group. CRP was increased $9.03 \pm 6.86 \mathrm{mg} /$ $\mathrm{dL}$ in the talc group and $6.3 \pm 7.5 \mathrm{mg} / \mathrm{dL}(p=0.366)$ in the Viscum group. NRS was increased $1.4 \pm 1.6$ in the talc group and $0.5 \pm 1.5$ in the Viscum group $(p=0.108)$ (Table 3).

\section{Imaging results of treatment response in both groups within 4 weeks after the last pleurodesis}

Regarding the final response after pleurodesis, $36.7 \%$ in the talc group and $60.0 \%$ in the Viscum group showed complete responses, $56.7 \%$ in the talc group and $36.0 \%$ in the Viscum group showed partial responses, and $6.7 \%$ in the talc group and $4.0 \%$ in the Viscum group showed treatment failure.

\section{Complications}

There was one acute respiratory distress syndrome (ARDS) and one pneumonitis in the talc group and one ARDS in the Viscum group. There was no death due to pleurodesis.
Table 3 Difference between before and after pleurodesis

\begin{tabular}{lccl}
\hline & \multicolumn{1}{l}{ Talc } & \multicolumn{1}{l}{ Viscum } & $P$ value \\
\hline Body temperature $\left({ }^{\circ} \mathrm{C}\right)$ & $1.1 \pm 0.7$ & $1.1 \pm 0.5$ & 0.902 \\
Pain (NRS) & $1.4 \pm 1.6$ & $0.4 \pm 1.3$ & 0.092 \\
WBC (cells $\left./ \mathrm{mm}^{3}\right)$ & $4154.8 \pm 6710.7$ & $2086.5 \pm 6285.2$ & 0.3 \\
CRP $(\mathrm{mg} / \mathrm{dL})$ & $9.03 \pm 6.86$ & $4.39 \pm 8.26$ & 0.199 \\
\hline
\end{tabular}

\section{Discussion}

The goal of performing chemical pleurodesis in patients with MPE is palliation, not definite treatment. Patients who suffer from dyspnea or chest pain are subject to discomfort due to repetitive hospitalization and treatment, resulting in reduced quality of life. Treatment of MPE includes repetitive thoracentesis, indwelling pleural catheter, and other methods [4-6]. However, chemical pleurodesis is still the most common treatment [7-11]. Generally, chemical pleurodesis can be performed through video-assisted thoracic surgery (VATS) or a chest tube at the bedside. However, VATS has potential risks associated with general anesthesia and surgery. Therefore, in the case of physician's judgment or patient's request, chemical pleurodesis is often performed at the bedside.

Agents used for chemical pleurodesis can vary, including tetracycline, minocycline, doxycycline, and iodopovidone. [2, $6,7,12,13]$. Traditionally, talc is known to be the most effective agent. The success rate of talc pleurodesis ranges from 81 to $100 \%$ [2, 7, 8, 14-16]. On the other hand, there have been various reports on the success rate of Viscum pleurodesis [17-19]. Cho et al. have reported that $96.7 \%$ had overall response rate, and $79 \%$ had complete response rate after chemical pleurodesis using ABNOVA Viscum ${ }^{\circledR}$ Injection for MPE [17]. In the results of this study, there was no statistically significant difference in the success rate of chemical pleurodesis between the talc group and the Viscum group (93.7\% vs. $96.0 \%, p=0.225$ ).

Talc pleurodesis has been associated with minor complications such as pain and fever, and major complications such as lung injury [20-24]. Since respiratory failure and death have
Table 2 Study outcomes after pleurodesis

\begin{tabular}{llll}
\hline & Talc $(n=30)$ & Viscum $(n=27)$ & $P$ value \\
\hline Duration of drainage after tube thoracostomy (day) & $11.5 \pm 8.1$ & $12.9 \pm 6.1$ & 0.495 \\
Duration of drainage after pleurodesis (day) & $4.6 \pm 4.7$ & $6.0 \pm 5.0$ & 0.345 \\
Total drainage after pleurodesis (ml) & $476.0 \pm 601.4$ & $1047.6 \pm 1321.7$ & 0.05 \\
Body temperature (high fever within 2 days) & $37.7 \pm 0.7$ & $37.6 \pm 0.5$ & 0.579 \\
Pain(NRS) & $2.7 \pm 1.3$ & $2 \pm 1.3$ & 0.154 \\
WBC (cells/mm ${ }^{3}$ ) & $12,046.3 \pm 6208.3$ & $13,820.8 \pm 6414.2$ & 0.416 \\
CRP (mg/dL) & $16.09 \pm 9.04$ & $9.90 \pm 7.25$ & 0.092 \\
\hline
\end{tabular}

$N R S$ numeric rating scale, $W B C$ white blood cell, $C R P$ C-reactive protein 
also been reported in pleurodesis using a small amount of talc [25], the authors used only $2 \mathrm{~g}$ of talc to prevent respiratory failure. Thus, there has been continuing effort to find agents that are as effective as talc while having fewer complications than talc. In this study, the authors compared various clinical outcomes during the course of chemical pleurodesis performed with talc and Viscum album extract for MPE. Viscum was first used in chemical pleurodesis in 1977 [26]. Basic mechanisms involved in chemical pleurodesis are quite different from between talc and Viscum. The most crucial difference is that talc induces inflammation while Viscum stimulates antitumor immunity. Viscum is also known to induce inflammation [27-33]. Because of this mechanism, this study also showed that the duration of drainage of the pleural fluid tended to be relatively long in the Viscum group after pleurodesis $[17,30]$. However, the common discomfort experienced by most patients with chemical pleurodesis is pleuritic pain or fever. In relation to chemical pleurodesis, the authors want to learn more about "discomfort" such as fever and chest pain that patients most often experience.

In this study, we evaluated the degree of pain suffered by patients using the numeric rating scale (NRS) [34, 35]. Although this is a study of patients with pneumothorax, Song et al. have reported that only $13.5 \%$ of the Viscum group have complaints of severe pain $(p=0.006)$, and the mean value of NRS is $3.9 \pm 2.2$ after pleurodesis with Viscum [36]. However, we wanted to not only see the absolute value of NRS but also change patterns of values after chemical pleurodesis. According to our results, the talc group and the Viscum group showed similar results in NRS after the pleurodesis $(2.7 \pm 1.3$ vs $2.5 \pm 1.7, p=0.7)$. However, the Viscum group showed smaller change in NRS between before and after the procedure (talc vs. Viscum, $1.4 \pm 1.6$ vs. $0.5 \pm$ $1.5, p=0.108$ ). The degree of "discomfort" felt by patients with pleurodesis was not statistically different between the two groups, although patients in the Viscum group were relatively less afflicted.

Besides pain, the common discomfort felt by patients after pleurodesis is fever. According to previous studies of Froudarakis et al. based on the rise in WBC count and CRP levels, fever is caused by systemic inflammation after talc pleurodesis [20]. In this regard, the authors also analyzed changes in body temperature and inflammatory factors such as WBC and CRP. All three were statistically insignificant, although their changes in the Viscum group were smaller.

The intensity of the pain felt by patients and the degree of change in measured values related to the fever were similar between the two groups. However, patients in the Viscum group showed relatively less pain and less fever than the talc group, indicating a tendency to withstand relatively comfortable procedures.

This study has several limitations. First, the accuracy of medical record is questionable. In particular, due to the limitations of the retrospective study, there was no way to assess pain other than NRS, and this was often missing. In addition, some past medical records of patients were missing. From a technical point of view, the position of the chest tube might have affected the outcome, since pleurodesis was done at the bedside.

In conclusion, Viscum pleurodesis showed comparable treatment results to talc pleurodesis. However, its adverse effects such as chest pain and fever tended to be relatively weak.

Authors' contributions All authors participated in the design of the study and coordination and helped to draft the manuscript. All authors read and approved the final manuscript.

\section{Compliance with ethical standards}

Conflict of interest The authors declare that they have no conflict of interest.

Informed consent Written informed consent was obtained from the patient for publication of this original article and any accompanying images. A copy of the written consent is available for review by the Editor-inChief of this journal. This study was approved by the Institutional Review Board for St. Vincent's Hospital (VC17RESI0120).

Open Access This article is licensed under a Creative Commons Attribution 4.0 International License, which permits use, sharing, adaptation, distribution and reproduction in any medium or format, as long as you give appropriate credit to the original author(s) and the source, provide a link to the Creative Commons licence, and indicate if changes were made. The images or other third party material in this article are included in the article's Creative Commons licence, unless indicated otherwise in a credit line to the material. If material is not included in the article's Creative Commons licence and your intended use is not permitted by statutory regulation or exceeds the permitted use, you will need to obtain permission directly from the copyright holder. To view a copy of this licence, visit http://creativecommons.org/licenses/by/4.0/.

\section{References}

1. Feller-Kopman DJ, Reddy CB, DeCamp MM, Diekemper RL, Gould MK, Henry T, Iyer NP, Lee YCG, Lewis SZ, Maskell NA, Rahman NM, Sterman DH, Wahidi MM, Balekian AA (2018) Management of malignant pleural effusions an official ATS/STS/ STR clinical practice guideline. Am J Respir Crit Care Med 198: 839-849

2. Scarci M, Caruana E, Bertolaccini L et al (2017) Current practices in the management of malignant pleural effusions: a survey among members of the European Society of Thoracic Surgeons. Interact Cardiovasc Thorac Surg 24:414-417

3. World Health Organization. Geneva, Switzerland (1979) WHO Handbook for reporting results of cancer treatment: No.48

4. Davies HE, Mishra EK, Kahan BC et al (2012) Effect of an indwelling pleural catheter vs. chest tube and talc pleurodesis for relieving dyspnea in patients with malignant pleural effusion: the TIME2 randomized controlled trial. JAMA 13:2383-2389

5. Reddy CB, DeCamp MM, Diekemper RL, Gould MK, Henry T, Iyer NP, Lee YCG, Lewis SZ, Maskell NA, Rahman NM, Sterman 
DH, Wahidi MM, Balekian AA, Feller-Kopman DJ (2019) Summary for clinicians: clinical practice guideline for management of malignant pleural effusions. Ann Am Thorac Soc 16:17-21

6. Clive AO, Bhatnagar R, Preston NJ, Maskell NA, Jones HE (2016) Cochrane corner: interventions for the management of malignant pleural effusions. Thorax 71:964-966

7. Koegelenberg CFN, Shaw JA, Irusen EM, Lee YCG (2018) Contemporary best practice in the management of malignant pleural effusion. Ther Adv Respir Dis 12:1-13

8. Roberts ME, Neville E, Berrisford RG, Antunes G, Ali NJ, BTS Pleural Disease Guideline Group (2010) Management of a malignant pleural effusion: British Thoracic Society Pleural Disease Guideline 2010. Thorax 65(suppl 2):ii32-ii40

9. Thomas R, Francis R, Davies HE, Lee YC (2014) Interventional therapies for malignant pleural effusions: the present and the future. Respirology 19:809-822

10. Neragi-Miandoab S (2006) Malignant pleural effusion, current and evolving approaches for its diagnosis and management. Lung Cancer 54:1-9

11. Tan C, Sedrakyan A, Browne J, Swift S, Treasure T (2006) The evidence on the effectiveness of management for malignant pleural effusion: a systematic review. Eur J Cardiothorac Surg 29:829-838

12. Azzopardi M, Porcel JM, Koegelenberg CF, Lee YC, Fysh ET (2014) Current controversies in the management of malignant pleural effusions. Semin Respir Crit Care 35:723-731

13. Guinde J, Georges S, Bourinet V, Laroumagne S, Dutau H, Astoul P (2018) Recent developments in pleurodesis for malignant pleural disease. Clin Respir J 12:2463-2468

14. Shaw P, Agarwal R (2004) Pleurodesis for malignant pleural effusions. Cochrane Database Syst Rev 11:CD002916

15. Clive AO, Jones HE, Bhatnagar R, Preston NJ, Maskell N (2016) Interventions for the management of malignant pleural effusions: a network meta-analysis. Cochrane Database Syst Rev 5:CD010529

16. Santos PS, Marques MA, Cruz C, Monteiro H, Fradinho F (2017) Predictors of talc slurry pleurodesis success in patients with malignant pleural effusions. Rev Port Pneumol 23:216-220

17. Cho JS, Na KJ, Lee Y et al (2016) Chemical pleurodesis using mistletoe extraction (ABNOVAviscum injection) for malignant pleural effusion. Ann Thorac Cardiovasc Surg 22:20-26

18. Gaafar R, Abdel Rahman AR, Aboulkasem F, El Bastawisy A (2014) Mistletoe preparation (Viscum Fraxini-2) as palliative treatment for malignant pleural effusion: a feasibility study with comparison to bleomycin. Ecancermedicalscience 8:424

19. Shaw JA, Koegelenberg CFN (2018) Malignant pleural effusions: mistletoe spray instead of talc poudrage? Respiration 95:143-144

20. Froudarakis M, Klimathianaki M, Pougounias M (2006) Systemic inflammatory reaction after thoracoscopic talc poudrage. Chest 129:356-361

21. Janssen JP, Collier G, Astoul P, Tassi GF, Noppen M, RodriguezPanadero F, Loddenkemper R, Herth FJ, Gasparini S, Marquette $\mathrm{CH}$, Becke B, Froudarakis ME, Driesen P, Bolliger CT, Tschopp JM (2007) Safety of pleurodesis with talc poudrage in malignant pleural effusion: a prospective cohort study. Lancet 369:1535-1539
22. Rehse DH, Aye RW, Florence MG (1999) Respiratory failure following talc pleurodesis. Am J Surg 177:437-440

23. Light RW (2000) Talc should not be used for pleurodesis. Am J Respir Crit Care Med 162:2024-2026

24. Light RW (2012) Counterpoint:should thoracoscopic talc pleurodesis be the first choice management for malignant pleural effusion? No. Chest 142:17-19 discussion 19-20

25. Campos JR, Werebe EC, Vargas FS et al (1997) Respiratory failure due to insufflated talc. Lancet 349:251-252

26. Salzer G (1977) The local treatment of malignant pleural exudations with iscador (a drug obtained from misteltoe): preliminary report (author's transl). Osterr Z Onkol 4:13-14

27. Mueller EA, Anderer FA (1990) A Viscum album oligosaccharide activating human natural cytotoxicity is an interferon gamma inducer. Cancer Immunol Immunother 32:221-227

28. Bussing A, Regnery A, Schweizer K (1995) Effects of Viscum album L. on cyclophosphamide-treated peripheral blood mononuclear cells in vitro: sister chromatid exchanges and activation/ proliferation marker expression. Cancer Lett 94:199-205

29. Evans M, Bryant S, Huntley AL, Feder G (2016) Cancer patients' experiences of using mistletoe (Viscum album): a qualitative systematic review and synthesis. J Altern Complement Med 22:134 144

30. Stumpf C, Bussing A (1997) Stimulation of antitumour immunity by intrapleural instillation of a Viscum album L. extract. AntiCancer Drugs 8(Suppl 1):S23-S26

31. Nasreen N, Mohammed KA, Dowling PA, Ward MJ, Galffy G, Antony VB (2000) Talc induces apoptosis in human malignant mesothelioma cells in vitro. Am J Respir Crit Care Med 161:595600

32. Nasreen N, Mohammed KA, Brown S et al (2007) Talc mediates angiostasis in malignant pleural effusions via endostatin induction. Eur Respir J 29:761-769

33. Salzer G (1986) Pleura carcinosis. cytomorphological findings with the mistletoe preparation iscador and other pharmaceuticals. Oncology 43(suppl 1):66-70

34. Eriksson K, Wikstrom L, Arestedt K, Fridlund B, Brostrom A (2014) Numeric rating scale: patients' perceptions of its use in postoperative pain assessments. Appl Nurs Res 27:41-46

35. Farrar JT, Troxel AB, Stott C, Duncombe P, Jensen MP (2008) Validity, reliability, and clinical importance of change in a $0-10$ numeric rating scale measure of spasticity: a post hoc analysis of a randomized, double-blind, placebo-controlled trial. Clin Ther 30: 974-985

36. Song KS, Keum D, Kim JB (2017) Chemical pleurodesis using doxycycline and Viscum album extract. Korean $\mathrm{J}$ Thorac Cardiovasc Surg 50:281-286

Publisher's note Springer Nature remains neutral with regard to jurisdictional claims in published maps and institutional affiliations. 